\title{
The influence of chemotherapy on adenosine-producing B cells in patients with head and neck squamous cell carcinoma
}

\author{
Andreas Ziebart ${ }^{1,2}$, Ulrich Huber ${ }^{2}$, Sandra Jeske ${ }^{2}$, Simon Laban², Johannes Doescher ${ }^{2}$, \\ Thomas K. Hoffmann ${ }^{2}$, Cornelia Brunner ${ }^{2}$, Edwin K. Jackson ${ }^{3}$ and Patrick J. Schuler ${ }^{2}$ \\ ${ }^{1}$ Department of Neurosurgery, University Hospital Mannheim, University of Heidelberg, Mannheim, Germany \\ ${ }^{2}$ Department of Otolaryngology, Head and Neck Surgery, Ulm University Medical Center, Ulm, Germany \\ ${ }^{3}$ Department of Pharmacology and Chemical Biology, University of Pittsburgh School of Medicine, Pittsburgh, Pennsylvania, \\ USA \\ Correspondence to: Patrick J. Schuler, email: patrick.schuler@uniklinik-ulm.de \\ Keywords: regulatory B cells; adenosine; head and neck cancer; cisplatin; methotrexate \\ Received: October 05, $2017 \quad$ Accepted: December 01, $2017 \quad$ Published: December 20, 2017 \\ Copyright: Ziebart et al. This is an open-access article distributed under the terms of the Creative Commons Attribution License \\ 3.0 (CC BY 3.0), which permits unrestricted use, distribution, and reproduction in any medium, provided the original author and \\ source are credited.
}

\section{ABSTRACT}

Introduction: Head and neck squamous cell carcinoma (HNSCC) strongly suppresses the immune system, resulting in increased metastasis and recurrent disease. Chemotherapy is part of the multimodal treatment but may further immunosuppression. Recently, we demonstrated that regulatory B cells (Breg), defined as CD19+CD39+CD73+ $\mathrm{B}$ cells, play a significant role in the production of immunosuppressive, extracellular adenosine (ADO). Here, we tested the influence of chemotherapy on Breg function.

Results: In HNSCC patients, Breg were diminished in absolute number and frequency after chemotherapy (paired samples). Chemotherapeutic drugs had variable effects; while platinum-based chemotherapy decreased the expression of CD39, methotrexate led to a functional increase in CD39 expression and increased production of immunosuppressive ADO. These findings were confirmed in a second patient cohort. Surface expression of CD39 correlated strongly with the production of ADO as measured by mass spectrometry.

Conclusions: Platinum-based anti-tumor-therapy reduces the number of adenosine-producing $B$ cells and, consequently, potential immunosuppression within the tumor environment. Breg function in terms of ADO production and their potential capacity to suppress $\mathrm{CD4}^{+} \mathrm{T}$ cells are promoted by methotrexate treatment amplifying anti-inflammatory therapeutic effects. Our results add to the understanding of how chemotherapeutic drugs can influence the human immune system and may therefore help to orchestrate standard oncologic therapy with new immune modulating approaches.

Methods: Mononuclear cells were collected prospectively from HNSCC patients before and after chemotherapy $(n=18)$, from healthy donors $(n=20)$, and an additional cohort sampled several months after chemotherapy $(n=14)$. Frequency, phenotype, and function of Breg were determined by multicolor flow cytometry, ATP luminescence assay as well as mass spectrometry measuring 5'-AMP, ADO, and inosine. Isolated B cells were incubated with chemotherapeutic drugs (cisplatin, methotrexate, paclitaxel, 5-fluorouracil) in vitro for functional studies. 


\section{INTRODUCTION}

\section{$B$ cells in cancer}

The role of tumor-infiltrating B lymphocytes (TIL-B) in solid cancers has long been strongly underestimated [1]. It has recently become clear, that the presence of TIL-B frequently correlates with a good prognosis in a variety of solid cancers, including breast, colon, and lung cancer as well as head and neck squamous cell carcinoma (HNSCC) [2-4]. Furthermore, it has been suggested that the relevance of TIL-B as a prognostic marker may exceed the role of $\mathrm{CD} 8^{+} \mathrm{T}$ lymphocytes, given that the interaction of both cell types is mandatory for a sufficient anti-tumor response [5]. Additionally, their controversial function includes a tumorpromoting role [6] and moreover, several murine tumor models implement a pro-tumor effect of TIL-B [7, 8]. In addition, $\mathrm{B}$ cells inhibit the anti-tumor effect of vaccination against murine malignant melanoma and they induce radioresistance in murine prostate cancer $[9,10]$. This effect may be partly explained by conversion and attraction of regulatory $\mathrm{T}$ cells (Treg) into the tumor micro-environment [1]. However, it also reiterates the difficulty in correlating murine models with the human system.

Nevertheless, it may be worthwhile to further subdivide the $\mathrm{B}$ cell population into immune competent $\mathrm{B}$ cells and regulatory B cells (Breg). Breg are commonly characterized by their potential to produce immune suppressive mediators, e.g. IL-10 and granzyme B [11, 12]. In humans, the presence of IL-10 producing regulatory TIL-B (TIL-Breg) is associated with a worse prognosis in HNSCC and gastric cancer [13, 14]. Similarly, the increased frequency of circulating Breg is correlated with advanced tumor stages in human hepatocellular carcinoma [15]. It has further been shown that TIL-Breg suppress the proliferation of $\mathrm{CD}^{+}$and $\mathrm{CD} 8^{+} \mathrm{T}$ cells as well as NK cells requiring a direct cell contact [16]. Additionally, IL-10 secreting TIL-Breg induce immunosuppressive regulatory $\mathrm{T}$ cells in breast cancer patients [17].

\section{$B$ cells and adenosine}

Our research team recently described a new group of Breg defined by their ability to produce immune suppressive adenosine (ADO) from exogenous ATP using ectonucleotidases CD39 and CD73 [18]. The coexpression of both enzymes is found in the majority ( $>65 \%)$ of all peripheral B cells in healthy donors. As we have previously shown, a variety of other immune cell populations also carry CD39 and/or CD73 on their surface, including regulatory T cells (Treg) [19], mesenchymal stem cells (MSC) [20], T helper cells [21] as well as noncellular exosomes [22]. However, among the immune cells B lymphocytes display the highest CD39/CD73 expression and the largest potential for production of $\mathrm{ADO}$ [18]. In addition, several tumor cell lines have also been shown to express ectonucleotidases, contributing to ADO metabolism [23].

\section{Adenosine in cancer}

Recently, the role of adenosine in the progression of solid cancers has been discovered and investigated in detail [24]. In the tumor micro-environment of HNSCC, Treg upregulate the expression of ectonucleotidases [25]. In contrast, MSC display a decreased production of ADO when isolated from HNSCC tissue and compared to MSC from autologous healthy tissue [20]. Tumor cells of HNSCC and prostate cancer are stimulated by ADO via $\mathrm{ADO}$ receptor $\left(\mathrm{ADOR}_{\mathrm{A} 2}\right)$ in vitro, indicating a protumorigenic effect of exogenous ADO [26, 27]. In humans, the ectonucleotidase CD73 is a strong and independent prognostic marker in a large number of ovarian cancer and prostate cancer patients and is correlated with poor outcome $[28,29]$. Both the immune suppressive effect and tumor-promoting effect make ADO an interesting therapeutic target. The ADO pathway can be inhibited either by inhibition of the enzymes CD39 and CD73 or by the blockade of ADO-specific receptors. While the modulation of CD39 is still in preclinical testing, an antibody against CD73 has recently entered the clinical trials stage for solid tumors (phase I, NCT02503774). Interestingly, caffeine acts as a natural inhibitor of $\mathrm{ADOR}_{\mathrm{A} 2 \mathrm{a}}$ and reduced tumor growth in a murine 3-MCA and melanoma model [30]. Similarly, the blockade of $\mathrm{ADOR}_{\mathrm{A} 2 \mathrm{a}}$ increases the efficacy of an anti-PD1 therapy in a murine breast carcinoma model $[31,32]$. Based on these promising findings, a selective $\mathrm{ADOR}_{\mathrm{A} 2 \mathrm{a}}$ inhibitor is currently being tested in a clinical trial for advanced non-small cell lung cancer (phase I, NCT02403193). In summary, inhibition of ADO receptors can have two beneficial effects for cancer patients: (I) improved functionality of immune cells, and (II) decreased proliferation of cancer cells, making this a promising treatment option.

Despite the importance of ADO in cancer progression, very little is known about the influence of cancer therapy on ADO-producing immune cell populations. It is now clear that the frequency of Treg is slightly increased in patients with HNSCC. However, after chemoradiotherapy (CRT) the frequency of peripheral $\mathrm{CD} 9^{+}$Treg increases dramatically due to their relative resistance to CRT as compared to $\mathrm{CD}^{+}{ }^{+} \mathrm{T}$ helper cells [33]. This may contribute to increased ADO levels and further immune suppression resulting in recurrent disease after CRT. Similarly, treatment with the EGF inhibitor cetuximab increased the frequency of $\mathrm{CD} 39^{+}$Treg in the micro-environment of HNSCC [34]. In contrast, a decrease in frequency and number of $\mathrm{CD} 39^{+}$Treg was observed after vaccination with $\mathrm{p} 53$-specific dendritic cells with a possible immune enhancing effect due to decreased ADO concentrations [35]. 
In the present study we describe for the first time the influence of chemotherapy on adenosine-producing Breg in two independent patient cohorts with HNSCC.

\section{RESULTS}

\section{Changes in frequency, absolute numbers and phenotype of $B$ cells before and after CRT}

For each HNSCC patient of cohort \#1, the frequency and absolute number of CD19 ${ }^{+} \mathrm{B}$ cells in the peripheral blood were compared before and after CRT. Both the frequency and the absolute number of $\mathrm{CD} 19^{+} \mathrm{B}$ cells were decreased (each $p<0.05$ ) after CRT (Figure 1A). Representative density plots are shown in Figure 1B. In cohort \#1, the frequency of $\mathrm{CD}^{+} \mathrm{T}$ cells also decreased significantly (Supplementary Figure 1A), while the frequency of $\mathrm{CD} 8^{+} \mathrm{T}$ cells was not significantly affected, confirming the data from previous publications [33]. While these changes applied to patients treated with a platinumbased chemotherapy, patients treated with methotrexate showed no alterations (Supplementary Figure 1B).

Furthermore, B cells in patient cohort \#1 were tested by flow cytometry for expression of various immunologic surface markers. IgM surface expression, as well as the $\operatorname{IgM}^{+} \mathrm{B}$ cell subset, were significantly increased after CRT (Supplementary Figure 1C). In addition, there was an increase in the $\mathrm{CD} 19^{+} \mathrm{CD}^{+} \mathrm{B}$ cell compartment after CRT, which is considered critical regarding the promotion of further tumor growth (Figure 1C, 1D) [37]. Both surface markers, IgM and CD5, were found to be unchanged after methotrexate therapy. B cells were negative for CD26 and no expression was induced by CRT. Expression rates and percentages of $\mathrm{CD}_{25} 5^{+}, \mathrm{PD}^{+}, \mathrm{CCR}^{+}, \mathrm{IgA}^{+}$, and $\mathrm{CD} 40^{+} \mathrm{B}$ cells also showed no significant alteration after treatment (Supplementary Figure 1E and $1 \mathrm{~F}$ ).

\section{Phenotypic characterization of ADO-producing $B$ cells}

In patient cohort \#1, flow cytometry analysis showed that up to $82 \%$ of B cells co-expressed CD39 and CD73 on their cell surface. As previously reported, these cells demonstrate an immunosuppressive potential by hydrolyzing exogenous ATP to ADP, 5'-AMP, and ADO [18]. Therefore, we were especially interested in therapyinduced changes in this Breg subset. Within the CD19 $\mathrm{B}$ cell compartment, the frequency and the absolute number of these CD $39^{+} \mathrm{CD} 73^{+}$Breg was significantly decreased after CRT $(p<0.005)$ (Figure 2A, 2B). Consequently, the subsets of $\mathrm{CD} 39^{+} \mathrm{CD} 73^{\text {neg }}$ as well as $\mathrm{CD} 39^{\text {neg }} \mathrm{CD} 73^{+} \mathrm{B}$ cells were increased ( $p<0.01$, data not shown). As shown in Figure 2C, the mean fluorescence intensity (MFI) of both ectonucleotidases, CD39 and CD73, was significantly reduced in the $\mathrm{CD} 19^{+} \mathrm{B}$ cell compartment after platinumbased chemotherapy $(p<0.001)$. Interestingly, MTX treatment showed no reduction in the ectonucleotidases
(Figure 2D) and also no decrease in co-expressing cells (Supplementary Figure 1D).

\section{In vitro changes by cytostatic drugs}

To test the different effects of cytostatic drugs on ADO-producing B cells, isolated B cells of healthy donors were treated with chemotherapy in vitro for 7 days as described above. Cytostatic drugs were chosen from regimens used in standard therapy for HNSCC patients in clinically administered concentrations (cisplatin, paclitaxel, 5-FU and MTX). Cisplatin, paclitaxel, and 5-FU induced a dose-dependent decrease in CD39 surface expression $(p<0.05)$. However, methotrexate induced a significant increase in CD39 expression on B cells $(p<0.05$, Figure 3A), while the mean fluorescence intensity of CD73 was significantly increased after incubation with cisplatin and paclitaxel (each $p<0.05)$. 5-FU and methotrexate did not influence surface expression of CD73 (Figure 3B). Cetuximab did not show either of these significant influences regarding the expression of CD39 and CD73 (data not shown).

\section{ATP hydrolysis by luminescence}

ATP is efficiently hydrolyzed to ADP and AMP by the enzymatic activity of CD39. To quantify the function of this enzyme and further evaluate the influence of chemotherapy, precultured B cells were separated and incubated with one of the cytostatic drugs. The same number of B cells $\left(3 \times 10^{4}\right)$ separated from the cultures were then analyzed in terms of ATP consumption by luminescence assay. Trypan blue dye was used for cell count and to determine viable cells. B cells cultured in the presence of high dose of cisplatin $(p<0.05)$, paclitaxel $(p<0.01)$, and 5-FU $(p<0.01)$ all showed lower ATP hydrolysis than B cells of the same healthy donors cultured in the absence of any cytostatic drug. Furthermore, 5-FU and paclitaxel each induced a significant reduction in ATP consumption, even in low or moderate dosages. In contrast, MTX showed a higher ATP hydrolyzation ( $p=0.1$; Figure 4A). There was a significant correlation between ATP utilization and CD39 expression for all samples $(p<0.0001)$, indicating a direct relationship (Figure 4B). This correlation was found to be particularly significant and dose-dependent in the presence of paclitaxel $(p<0.001$; Supplementary Figure 1G).

\section{Adenosine production measured by mass spectrometry}

In order to confirm results of ATP hydrolysis measured by luminescence, and therefore, functional characterization of the ectoenzymes CD39 and CD73, $\mathrm{ADO}$ production was measured by mass spectrometry. As expected, B cells showing downregulation of CD39 after treatment with cisplatin were less capable of ATP 
hydrolyzation and produced lower levels of 5'AMP. Due to the lack of substrate, production of ADO and inosine was also reduced. Despite the small number of samples, the data showed a trend towards significance in terms of ADO concentrations (no chemo vs. cisplatin; $p=0.07$ ). Figure 5 displays measurements of one representative patient including (A) expression of CD39 and CD73 by flow cytometry, (B) ATP consumption by luminescence, and $(\mathrm{C})$ mass spectrometry results. In accordance with our previous results, levels of $5^{\prime}$-AMP, ADO, and inosine were clearly higher in supernatants of B cell cultures incubated with MTX. While altered CD39 expression influenced consequent $\mathrm{ADO}$ production, $\mathrm{CD} 73$ varied less and seemed to play a minor role in ADO pathways.

\section{Drug-dependent suppression of B cell proliferation.}

B cells of healthy donors were incubated with cytostatic drugs, and proliferation was measured in CFSE-based proliferation assays as described above. Drugs in concentrations ranging from 1 to $50 \mu \mathrm{g} / \mathrm{mL}$ were added on day 0 . All drugs significantly inhibited B cell proliferation except for MTX (Figure 4C, 4D). Cisplatin almost completely blocked $\mathrm{B}$ cell proliferation

A
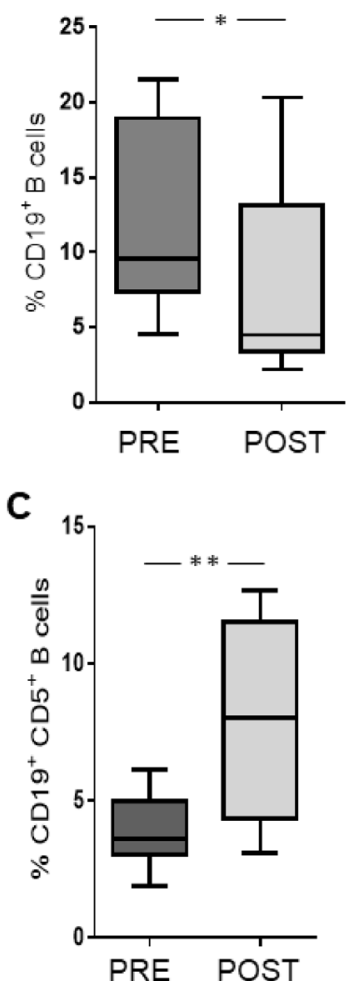
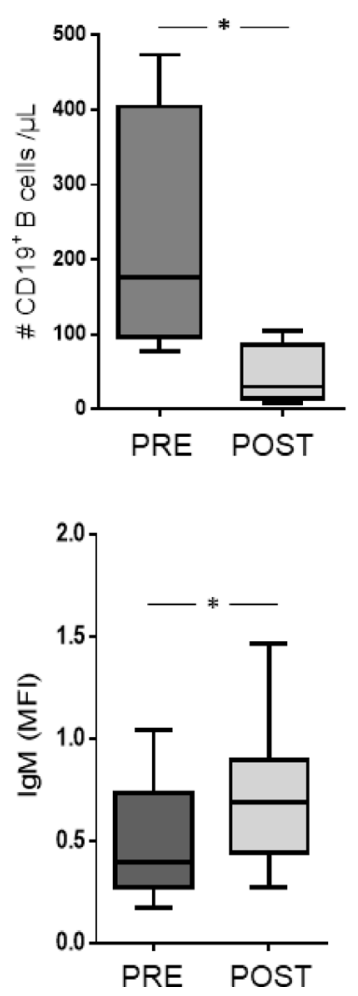

$(p<0.001)$. Paclitaxel decreased B cell proliferation in a dose-dependent manner (Supplementary Figure 2).

\section{Long-term effects of CRT}

Blood samples of patient cohort \#2 were collected $14.2 \pm 7$ months after CRT allowing for interpretation of longterm effects of CRT. The expression of the ectonucleotidases CD39 and CD73 were found to be decreased ( $p=0.01$ ); Figure 6A). However, the B cell frequency was significantly increased after CRT. In addition, there was a significant correlation between B cell frequency and time-after-treatment $(p<0.001)$ suggesting B cell population recovery after exposure to CRT (Figure 6B).

\section{DISCUSSION}

\section{Role of $B$ cells in cancer}

Effects of systemic cancer treatment on the host immune system are of considerable relevance. The interaction and function of immune cells is affected by any kind of therapy with a consequent reduction of antineoplastic activity. Recently, the role of tumorinfiltrating B cells has been a focus of various research groups and as described above, their impact on tumor

B

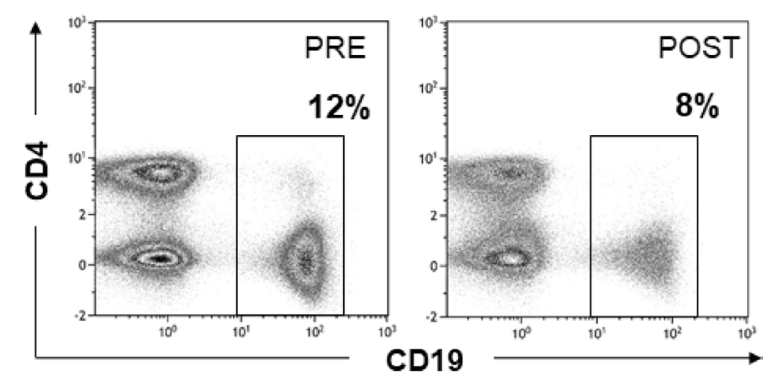

D

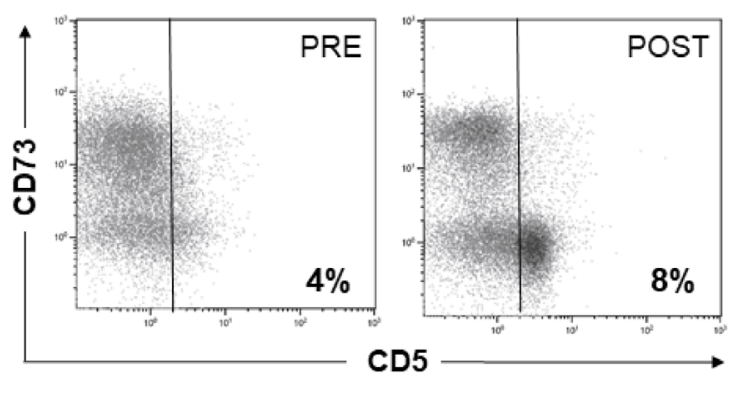

Figure 1: $(\mathbf{A})$ and $(\mathbf{B})$ The frequency $(n=15)$ and absolute number $(n=4)$ of B cells were significantly reduced in the peripheral blood of HNSCC patients after CRT as compared to pretreatment measurements. (C) CRT induced an increased expression of CD5 and IgM within the B cell compartment. (D) Density plot of one representative patient demonstrating an increasing portion of CD19+CD5+ B cells after CRT. 
growth has been underestimated in the past and is a matter of dispute. In particular, the role of tumor-infiltrating regulatory B cells (TIL-Breg) is not well understood [1]. However, it is reasonable to expect that adenosineproducing $\mathrm{B}$ cells have an immunosuppressive effect in the tumor micro-environment.

\section{Influence of cisplatin on B cells}

Here, we show for the first time the effect of systemic chemotherapy on Breg in cancer patients. Platinum-based therapy not only reduces the frequency of Breg but also their ability to produce immunosuppressive adenosine. This effect was demonstrated in vitro as well as in two independent cohorts of HNSCC patients. Our previous work has shown opposing effects on regulatory $\mathrm{T}$ cells, which are strongly enhanced in frequency and function by platinum-based chemotherapy [33]. It therefore becomes evident that oncologic therapy has different effects on regulatory cell populations in the human immune system. Based on the results of other research groups, tumor escape mechanisms apparently
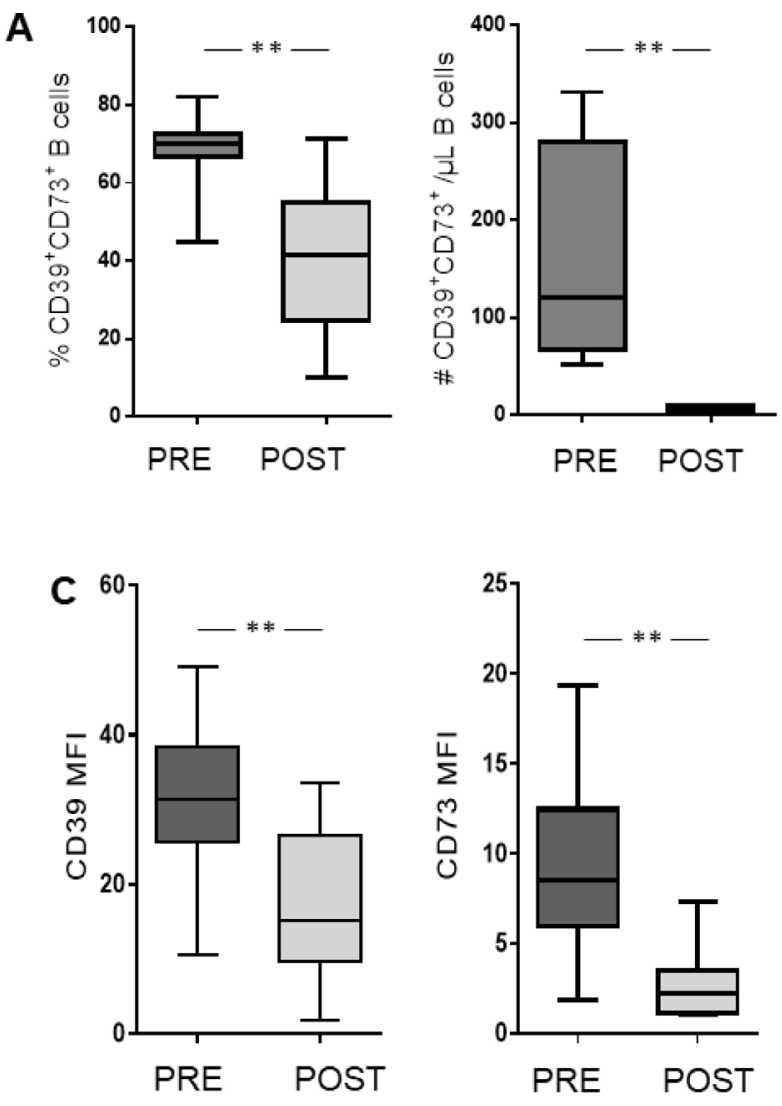

benefit from the presence of immunosuppressive ADO; the dysfunction of the ectonucleotidases CD39 and CD73 is associated with reduced tumor growth [38-40], and upregulation of CD73 on tumor cells is linked to increased risk for metastasis and increased chemo resistance [41-43]. However, other studies report antitumor effects of ADO [44-46], describing intracellular and extracellular mechanisms leading to apoptosis of cancer cells through ADO.

\section{Recovery of B cells}

In our second cohort of cancer patients, we could show that $\mathrm{B}$ cells have a fast recovery rate reaching normal levels about one year after termination of platinum-based chemotherapy. This is in contrast to our previous observations analyzing the Treg $\left(\mathrm{CD} 4^{+} \mathrm{FoxP}^{+}\right)$ population. There, we demonstrated that the frequency of Treg is increased for up to three years after chemotherapy [33]. Of note, the increased frequency of Treg after chemotherapy is caused by the decreased absolute number of $\mathrm{CD}^{+} \mathrm{T}$ cells. There was no increase observed
B
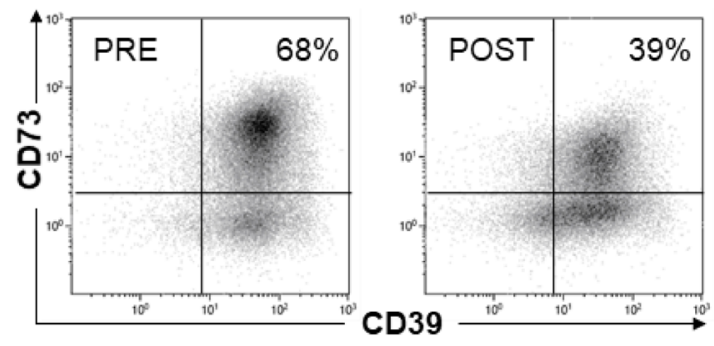

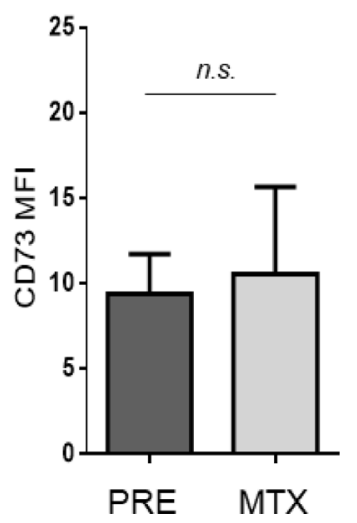

Figure 2: Phenotypic characterization of B cells in patients with HNSCC before and after treatment with CRT, respectively. Isolated PBMC were stained for flow cytometry and examined for surface expression of ectonucleotidases CD39 and CD73. (A) Frequency $(n=15)$ and absolute number $(n=4)$ of adenosine producing B cells defined by the co-expression of CD39 and CD73. (B) Density plot of one representative subject showing CD39 and CD73 expression in CD19+ gated cells. Percentages of CD19+CD39+CD73+ cells are indicated in the relevant quadrant. Box plots showing reduced surface expression of CD39 and CD73 as mean fluorescence intensity (MFI) in patients treated with cisplatin/carboplatin (C) while bar charts before and after methotrexate treatment are show no significant difference $(\mathbf{D})$. 

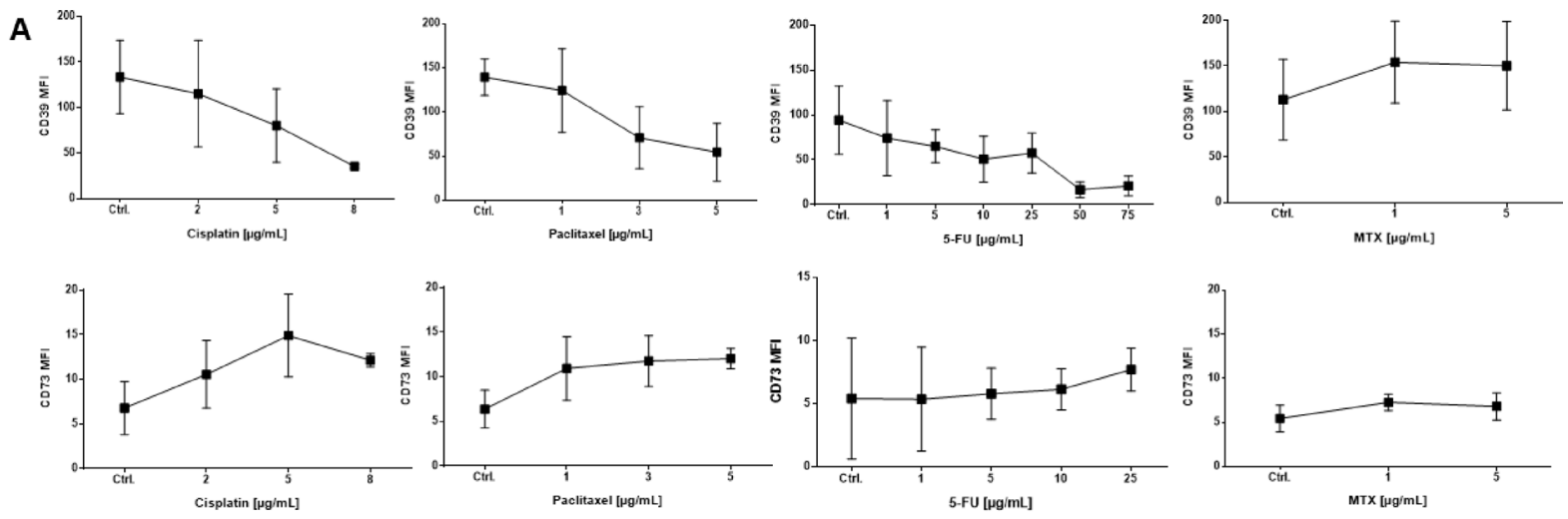

B
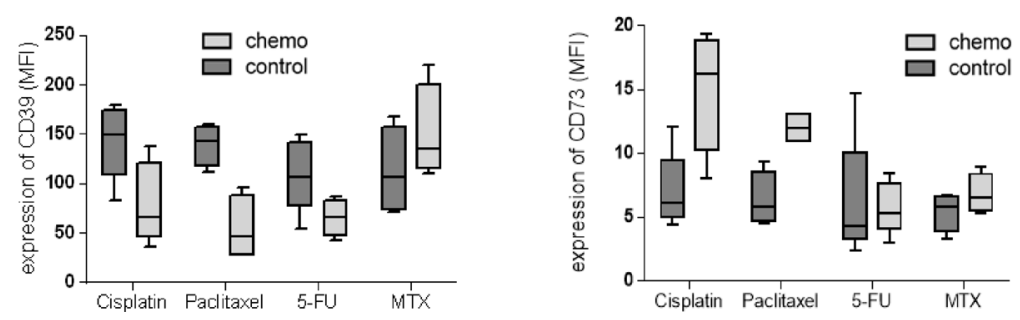

Figure 3: In vitro expression levels of CD39 and CD73 on B cells. Human B cells (precultured with IL-4, CD40L, and hemagglutinin) from healthy donors were separated as described and cultured in the presence of therapeutic concentrations of cytostatic drugs in RPMI medium. (A) Data are means \pm standard deviation determined for all CD19+ B cells obtained from at least 3 normal donors. (B) Box plots showing mean fluorescence intensity of CD39 and CD73 in B cells precultured with $5 \mu \mathrm{g} / \mathrm{mL}$ of one cytostatic drug, respectively.

A

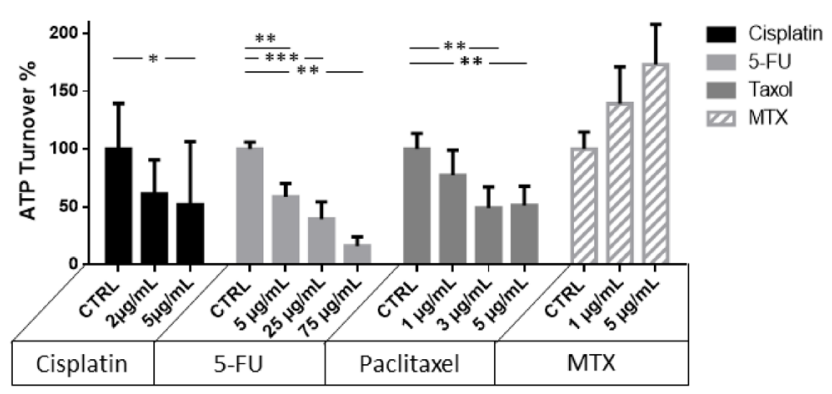

C

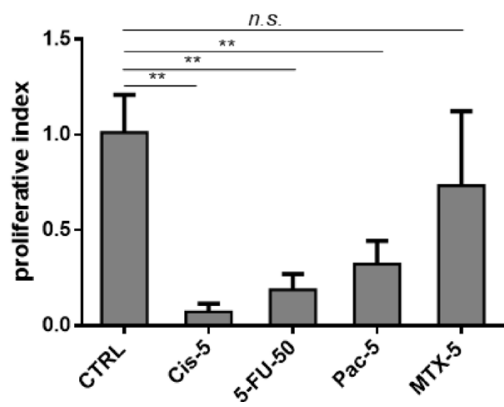

B
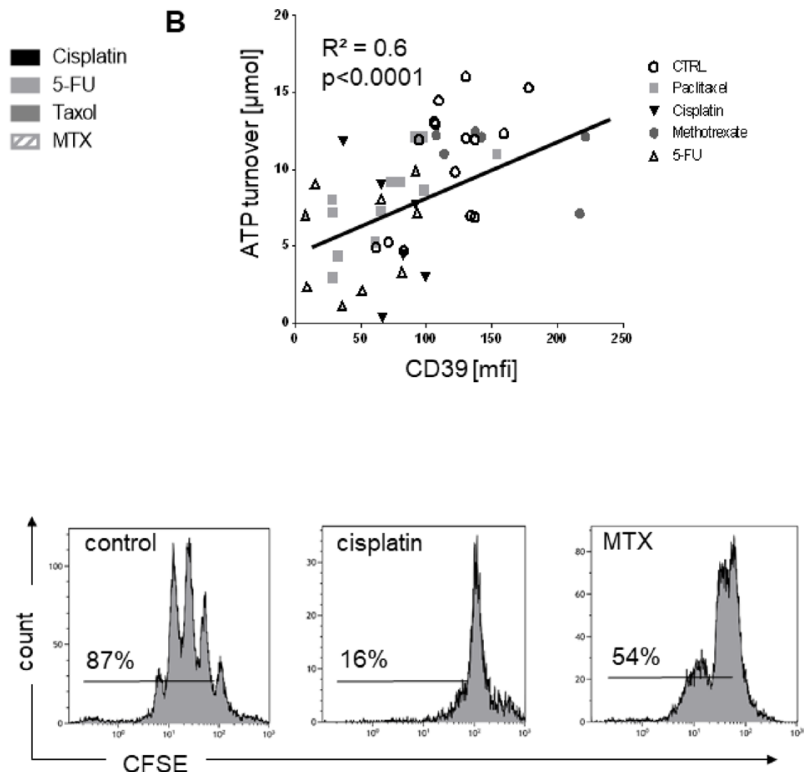

Figure 4: ATP hydrolysis, correlation to CD39 expression, and proliferation of B cells under influence of chemotherapy. (A) Utilization of exogenous ATP by B cells incubated with $20 \mu \mathrm{M}$ ATP after 90 minutes detected by luminescence measurement. The data are means \pm SD from three or more independent experiments with cells of different HCs each cultured in the presence of one cytostatic drug for 7 days before ATP add-on. Control measurements without treatment are set to $100 \%$ on the y-axis. (B) Spearman rank correlation of ATP hydrolysis and CD39 surface expression analyzed by flow cytometry. (C) Proliferation examined by dilution of CFSE: Left, average of at least three independent experiments, normalized to untreated controls; right, representative examples incubated with $1 \mu \mathrm{g} / \mathrm{mL}$ cisplatin and $10 \mu \mathrm{g} / \mathrm{mL}$ methotrexate. (C) Proliferation examined by dilution of CFSE. Average of at least three independent experiments, normalized to untreated controls. (D) representative examples incubated with $1 \mu \mathrm{g} / \mathrm{mL}$ cisplatin and $10 \mu \mathrm{g} / \mathrm{mL}$ methotrexate. 
in the absolute number of Treg. These data suggest that although CRT adversely affects both lymphocyte subsets, it has exceptionally detrimental effects on the $\mathrm{CD}^{+} \mathrm{T}$ cell population. CD19 ${ }^{+} \mathrm{B}$ cells seem to be less sensitive in the long-term since they recover faster from CRT than $\mathrm{CD}^{+}$ $\mathrm{T}$ cells. From an immunologic perspective, the altered lymphocyte homeostasis may partially explain, why HNSCC cells become resistant to an initially effective therapy.

\section{Influence of MTX on B cells}

When compared with platinum-based chemotherapy, MTX has an opposing effect on the human immune system. In our study population, Breg frequencies increased and showed enhanced ability to produce exogenous adenosine when patients were treated with MTX. These clinical data are supported by our in vitro experiments. MTX is not only used as an antineoplastic drug in cancer patients but also as an anti-inflammatory drug, e.g. in rheumatoid arthritis where it is used in a lower dose. Our results show an increased adenosine production in Breg induced by the presence of MTX, whose anti-inflammatory mechanism of action is not fully understood but is thought to be adenosine dependent [47]. It is further postulated by others that caffeine can suppress the therapeutic effect or unwanted side effects of MTX by targeting the adenosine receptors in an anti-inflammatory setting [47, 48]. The importance of the MTX-ADO axis is also confirmed by Tsujimoto et al. who found an association between MTX-induced leukencephalopathy and the polymorphism of the $\mathrm{ADO}$ receptor $\mathrm{A} 2 \mathrm{a}$ in pediatric leukemia patients [49]. Moreover, MTX was demonstrated to suppress the NFkappaB pathway by the release of ADO in Jurkat cells contributing to its antiinflammatory and antiproliferative effect [50]. Whether these observations can be translated into the antineoplastic effects of MTX in solid cancer patients is yet to be investigated.

Despite the analogy, caution is advised in extrapolating experimental results from arthritis patients to cancer patients as the diseases arise from entirely different conditions. Namely, it is not yet completely understood if immune suppression in the tumor micro-environment of cancer patients is beneficial or not. In addition, great differences may exist in the micro-environment of different kinds of cancer [22]. Interestingly, MTX may even have a promoting effect on adenosine metabolism in cancer cells as shown in glioblastoma cell lines due to the upregulation of the ectonucleotidase CD73 [51].

\section{Immunotherapy relies on a functional immune system}

Aside from the standard regimen of tumor therapy, e.g. surgery, radiation and chemotherapy, a variety of immunotherapeutic approaches have recently found their way into clinical routine. Special potential is seen in the checkpoint modulators, e.g. inhibitors of the programmed death receptor PD1, as they can lead to long-term survival
A
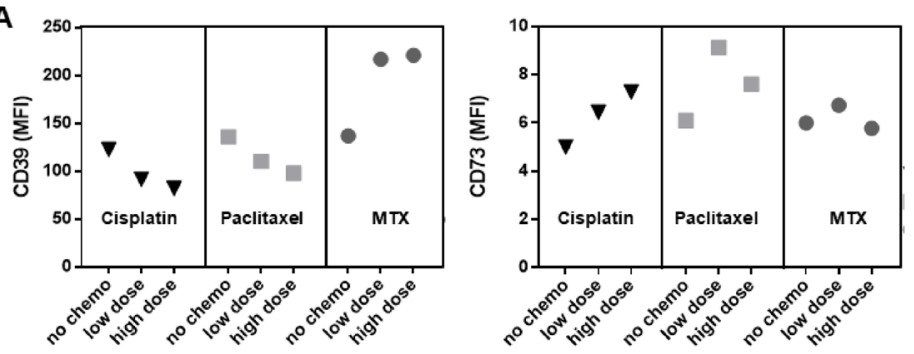

C

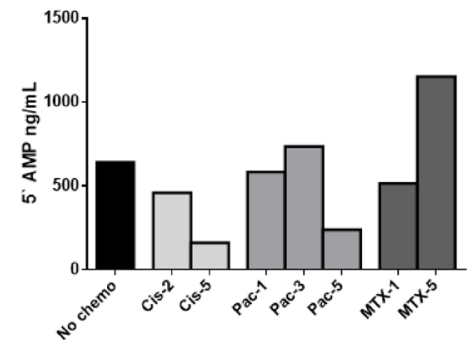

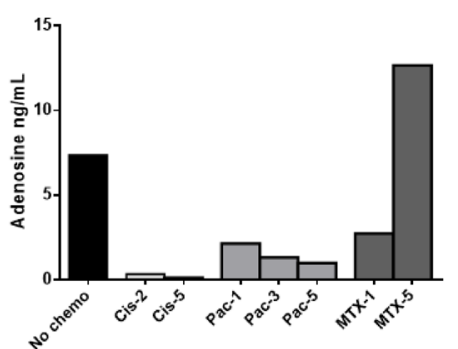

B
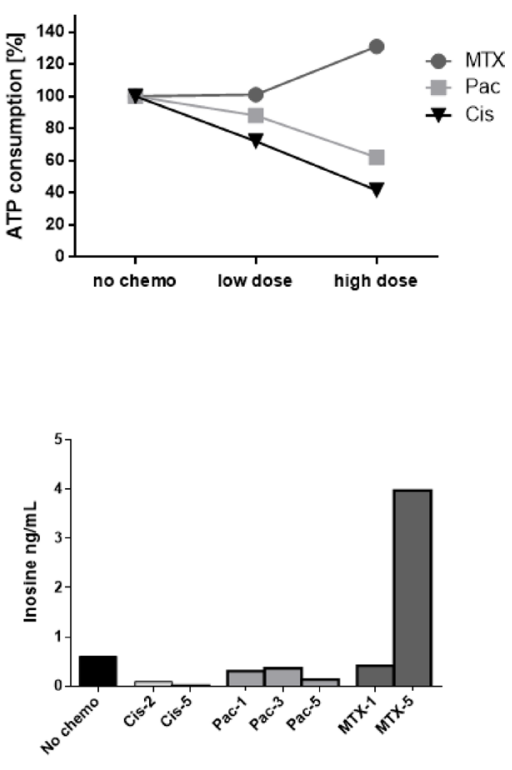

Figure 5: Correlation of B cell phenotype, ATP hydrolysis, and production of its derivates 5'AMP, ADO, and inosine. Juxtaposition of B cell treatment from one representative donor to confirm ATP hydrolysis and correlation with the respective phenotype. (A) Expression of ectonucleotidases after 7 days of cytostatic treatment as measured by flow cytometry. (B) ATP consumption as measured by luminescence. ATP concentrations measured without the influence of chemotherapeutic drugs were set to $100 \%$. (C) Production of 5'AMP, adenosine, and derivatives as measured by mass spectrometry. Decreased ATP hydrolysis and adenosine production correlated well with less CD39 expression after treatment with cisplatin and paclitaxel while methotrexate showed opposite effects. 
in advanced tumor disease [52]. All immunotherapeutic approaches rely on a functional immune system, and it is not yet clear how to optimally combine the different therapeutic regimens. Modified lymphocyte function and homeostasis induced by CRT could lead to therapy failure. This may be especially true for tumor cells arising from a chronic inflammatory setting, which is the case in $\mathrm{HPV}^{+} \mathrm{HNSCC}$. Here, the alteration of extracellular adenosine production may be added to the mechanisms, which result in therapy resistance. On the other hand, these processes may have the potential to overcome CRT failure in an immunosuppressive tumor microenvironment [53]. As recently demonstrated by Maj et al., regulatory cell populations can induce resistance to PD1-mediated therapy in the tumor microenvironment (TME). Due to the oxidative stress in the TME, the preferred mechanism of suppression is adenosine (and not PD-L1, CTLA-4, TGF-b, IL-35, or IL-10) [54]. These findings demonstrate the importance of adenosine in the context of immune suppression and therapeutic failure.

\section{CONCLUSIONS}

Our results add to the understanding of how chemotherapeutic drugs can influence the human immune system and may therefore help to orchestrate standard oncologic therapy with new immune modulating approaches. Giving consideration to the growing importance of tailored cancer treatment, further investigation of the interaction between antitumor immune response and systemic, oncologic therapy may be needed to adapt antineoplastic therapy regimes to individuals.

\section{MATERIALS AND METHODS}

\section{Patient cohort \#1}

Peripheral blood samples $(n=36)$ were obtained from $15 \mathrm{HNSCC}$ patients before and after CRT and from 3 patients before and after palliative chemotherapy (11/2013-10/2016). Healthy volunteers (NC, $n=20$ ) served as a control group for in vitro experiments.

\section{Patient cohort \#2}

An additional cohort of HNSCC patients $(n=14)$ donated peripheral blood after CRT, which was terminated $14.2 \pm 7$ months prior to the respective blood draws. At this time, none of the patients showed evidence of recurrent disease (NED). Blood samples were compared to an additional healthy control group $(\mathrm{NC}, n=24)$ in order to analyze long-term effects of CRT. All subjects signed
A

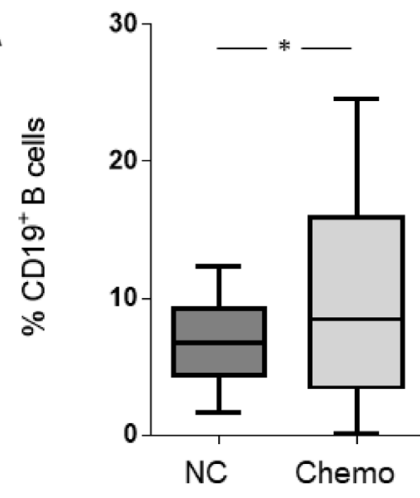

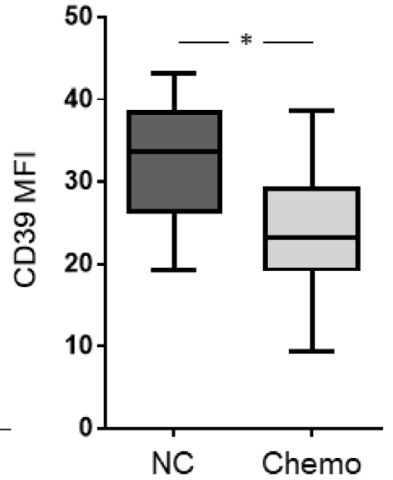

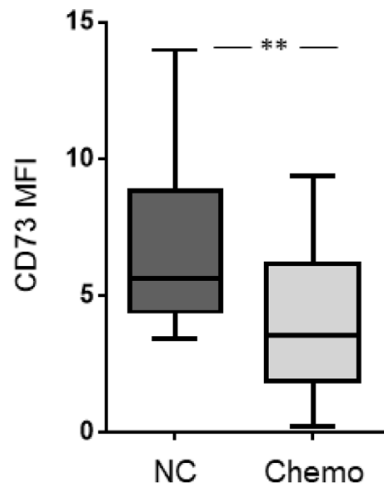

B

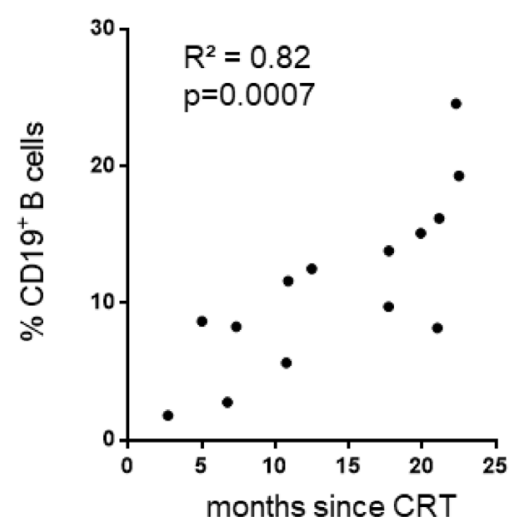

Figure 6: B cell frequency, CD39, and CD73 expression were evaluated in a second cohort of 14 patients with adjuvant CRT and 24 normal controls. (A) Boxplots show the frequency of B cells before and after CRT. The expression of CD39 and CD73 is decreased after CRT. (B) Course of B cell frequency correlated with time after CRT (2-23 months). 
Table 1: Patients' characteristics

\begin{tabular}{|c|c|c|c|c|}
\hline & Cohort \#1 & normal controls & Cohort \#2 & normal controls \\
\hline $\mathrm{N}$ (female/male) & $18(4 / 14)$ & $20(13 / 7)$ & $14(1 / 13)$ & $24(6 / 18)$ \\
\hline age (range) & $59 \pm 10(45-76)$ & $50 \pm 12(19-67)$ & $58 \pm 13(31-86)$ & $28 \pm 10(23-60)$ \\
\hline \multicolumn{5}{|l|}{ stage } \\
\hline $\mathrm{T} 1 / \mathrm{T} 2 / \mathrm{T} 3 / \mathrm{T} 4$ & $5 / 1 / 6 / 6$ & & $1 / 4 / 4 / 5$ & \\
\hline \multicolumn{5}{|l|}{ nodal status } \\
\hline N0/N1/N2 & $3 / 3 / 12$ & & $5 / 2 / 7$ & \\
\hline \multicolumn{5}{|l|}{ primary site } \\
\hline oral cavity & 8 & & 7 & \\
\hline pharynx & 4 & & 3 & \\
\hline larynx & 4 & & 3 & \\
\hline other & 2 & & 1 & \\
\hline \multicolumn{5}{|l|}{ chemotherapy } \\
\hline cisplatin & 13 & & 12 & \\
\hline carboplatin & 1 & & 2 & \\
\hline methotrexate & 3 & & & \\
\hline mitomycin & 1 & & & \\
\hline primary CRT & 8 & & 0 & \\
\hline adjuvant CRT & 7 & & 14 & \\
\hline palliative CT & 3 & & 0 & \\
\hline
\end{tabular}

an informed consent form approved by the respective local ethics committee (\# 255/14; IRB \#991206) according to the declaration of Helsinki. Clinicopathologic and demographic data for both patient cohorts are listed in Tables 1 and 2 .

\section{PBMC collection}

Blood samples $(50 \mathrm{~mL})$ were drawn into citratebuffered tubes and centrifuged on Ficoll-Hypaque gradients (Greiner Bio-one, Kremsmuenster, Austria). Peripheral blood mononuclear cells (PBMC) were recovered, washed twice with RPMI medium (RPMI 1640, Gibco, Grand Island, NY) and phosphate-buffered saline (PBS, Gibco), and counted in a trypan blue dye. PBMC from study cohort \#1 were cryo-conserved for subsequent analysis. PBMC from cohort \#2 were immediately used for in vitro experiments.

\section{FACS antibodies}

The following anti-human monoclonal antibodies $(\mathrm{mAb})$ were used for flow cytometry: CD4 AF700 (Cat 56-0048-82), CD73 FITC (Cat 11-0739-42), CD73 PE (Cat 12-0739-42), CD39 PE-Cy7 (Cat 25-0399-42), PD1 (CD279) PE (Cat 12-2799-42), and CCR7 (CD197) PE-
Cy7 (Cat 25-1979-42) mAb (all eBioscience, San Diego, CA); CD5 AF700 (Cat 561159), CD19 PE-Cy7 (Cat 555414), and IgM PE (Cat 555783) (all BD Pharmingen, Heidelberg, Germany); CD26 APC (Cat 302710), CD25 FITC (Cat 356105), and CD40 PE-Cy7 (Cat 334322) (all Biolegend, San Diego, CA); CD25 PE (Cat 130-101-426) and IgA APC (Cat 130-093-113) (Milenty Biotec, Bergisch Gladbach, Germany). All mAb were titrated using normal PBMC to establish optimal staining dilutions.

\section{Surface staining and flow cytometry}

Briefly, cells were incubated with mAb specific for surface markers in $50 \mu \mathrm{l}$ PBS for 30 minutes at room temperature in the dark and washed twice before acquisition for surface marker detection. Flow cytometry was performed using a Gallios ${ }^{\mathrm{TM}} 10$-color flow cytometer equipped with Kaluza ${ }^{\circledR}$ flow cytometry software (both Beckman Coulter, Brea, CA). The acquisition and analysis gates were restricted to the lymphocyte gate based on characteristic properties of the cells in forward and side scatter. At least $10^{5}$ cells were acquired for analysis. Absolute numbers of $\mathrm{CD} 19^{+} \mathrm{B}$ cells and $\mathrm{CD} 39^{+} \mathrm{CD} 73^{+}$ Breg were calculated by multiplying their frequency values by the absolute number of lymphocytes obtained from whole blood counts. 
Table 2: Patients' characteristics, cohort \#1

\begin{tabular}{|c|c|c|c|c|c|c|}
\hline$\#$ & primary site & stage & sex & age & chemotherapy & HPV \\
\hline$\# 1$ & oral cavity & T3N2cM0 & $\mathrm{f}$ & 49 & $\begin{array}{c}\text { primary CRT } \\
\text { CIS }\left(20 \mathrm{mg} / \mathrm{m}^{2} / \mathrm{d}, 2 \text { weeks }\right)\end{array}$ & neg. \\
\hline \#2 & oral cavity & T3N0M0 & $\mathrm{m}$ & 50 & $\begin{array}{c}\text { primary CRT } \\
\text { CIS }\left(40 \mathrm{mg} / \mathrm{m}^{2} / \mathrm{w}, 7 \text { weeks }\right)\end{array}$ & $\mathrm{n} / \mathrm{a}$ \\
\hline \#3 & oral cavity & T4aN2cM0 & $\mathrm{m}$ & 61 & $\begin{array}{c}\text { primary CRT } \\
\text { CIS }\left(40 \mathrm{mg} / \mathrm{m}^{2} / \mathrm{w}, 7 \text { weeks }\right)\end{array}$ & pos. \\
\hline$\# 4$ & oral cavity & T1N2bM0 & $\mathrm{m}$ & 68 & $\begin{array}{c}\text { primary CRT } \\
\text { CIS (40 mg/m²/w, } 7 \text { weeks) CARBO } \\
(\mathrm{AUC}-2,3 \text { weeks })\end{array}$ & pos. \\
\hline$\# 5$ & nasopharynx & T3N2bM0 & $\mathrm{m}$ & 60 & $\begin{array}{c}\text { primary CRT } \\
\text { CIS }\left(20 \mathrm{mg} / \mathrm{m}^{2} / \mathrm{d}, 2 \text { weeks }\right)\end{array}$ & $\mathrm{n} / \mathrm{a}$ \\
\hline$\# 6$ & larynx & $\mathrm{T} 3 \mathrm{~N} 2 \mathrm{cM} 0$ & $\mathrm{f}$ & 45 & $\begin{array}{c}\text { primary CRT } \\
\text { CIS }\left(40 \mathrm{mg} / \mathrm{m}^{2} / \mathrm{w}, 7 \text { weeks }\right)\end{array}$ & $\mathrm{n} / \mathrm{a}$ \\
\hline \#7 & oral cavity & $\mathrm{T} 2 \mathrm{~N} 2 \mathrm{bM} 0$ & $\mathrm{~m}$ & 68 & $\begin{array}{c}\text { primary CRT } \\
\text { CARBO (AUC-6, } 2 \text { weeks) }\end{array}$ & neg. \\
\hline$\# 8$ & pharynx & T4aN3bM0 & $\mathrm{m}$ & 76 & $\begin{array}{c}\text { primary CRT } \\
\text { MIT-C }\left(10 \mathrm{mg} / \mathrm{m}^{2} / \mathrm{w}, 2 \text { weeks }\right)\end{array}$ & $\mathrm{n} / \mathrm{a}$ \\
\hline \#9 & oral cavity & T3N2bM0 & $\mathrm{m}$ & 52 & $\begin{array}{c}\text { adjuvant CRT } \\
\text { CIS }\left(20 \mathrm{mg} / \mathrm{m}^{2} / \mathrm{d}, 2 \text { weeks }\right)\end{array}$ & neg. \\
\hline \#10 & oral cavity & T1N1M0 & $\mathrm{m}$ & 50 & $\begin{array}{c}\text { adjuvant CRT } \\
\text { CIS }\left(20 \mathrm{mg} / \mathrm{m}^{2} / \mathrm{d}, 2 \text { weeks }\right) \\
5-\mathrm{FU}\left(600 \mathrm{mg} / \mathrm{m}^{2} / \mathrm{w}, 2 \text { weeks }\right)\end{array}$ & neg. \\
\hline \#11 & pharynx & T1N2bM0 & $\mathrm{m}$ & 52 & $\begin{array}{c}\text { adjuvant CRT } \\
\text { CIS }\left(20 \mathrm{mg} / \mathrm{m}^{2} / \mathrm{d}, 2 \text { weeks }\right)\end{array}$ & $\mathrm{n} / \mathrm{a}$ \\
\hline \#12 & larynx & $\mathrm{T} 3 \mathrm{~N} 2 \mathrm{cM} 0$ & $\mathrm{~m}$ & 63 & $\begin{array}{c}\text { adjuvant CRT } \\
\text { CIS }\left(20 \mathrm{mg} / \mathrm{m}^{2} / \mathrm{d}, 2 \text { weeks }\right)\end{array}$ & $\mathrm{n} / \mathrm{a}$ \\
\hline \#13 & larynx & T4aN1M0 & $\mathrm{m}$ & 53 & $\begin{array}{c}\text { adjuvant CRT } \\
\text { CIS }\left(20 \mathrm{mg} / \mathrm{m}^{2} / \mathrm{d}, 2 \text { weeks }\right)\end{array}$ & $\mathrm{n} / \mathrm{a}$ \\
\hline$\# 14$ & larynx & T1aN0M0 & $\mathrm{m}$ & 70 & $\begin{array}{c}\text { adjuvant CRT } \\
\left.\text { CIS (30 } \mathrm{mg} / \mathrm{m}^{2} / \mathrm{w}, 7 \text { weeks }\right)\end{array}$ & $\mathrm{n} / \mathrm{a}$ \\
\hline \#15 & acoustic meatus & T4N1M0 & $\mathrm{f}$ & 64 & $\begin{array}{c}\text { adjuvant CRT } \\
\text { CARBO (AUC-6, } 2 \text { weeks) }\end{array}$ & $\mathrm{n} / \mathrm{a}$ \\
\hline$\# 16$ & oral cavity & T1N2bM1 & $\mathrm{f}$ & 46 & $\begin{array}{c}\text { palliative CT } \\
\text { MTX (40 mg/m²/w, } 6 \text { weeks) }\end{array}$ & pos. \\
\hline \#17 & pharynx & T4aN0M1 & $\mathrm{m}$ & 58 & $\begin{array}{c}\text { palliative CT } \\
\operatorname{MTX}\left(40 \mathrm{mg} / \mathrm{m}^{2} / \mathrm{w}, 6 \text { weeks }\right)\end{array}$ & neg. \\
\hline \#18 & pharynx & T4aN2bM1 & $\mathrm{m}$ & 74 & $\begin{array}{c}\text { palliative CT } \\
\operatorname{MTX}\left(40 \mathrm{mg} / \mathrm{m}^{2} / \mathrm{w}, 6 \text { weeks }\right)\end{array}$ & neg. \\
\hline
\end{tabular}

CRT: chemoradiotherapy; CIS: cisplatin $\left(30-40 \mathrm{mg} / \mathrm{m}^{2}\right.$ weekly for 7 weeks, or $20 \mathrm{mg} / \mathrm{m}^{2}$ daily in week 1 and 5); CARBO: carboplatin (AUC-area under the curve); MIT-C: mitomycin-C; 5-FU: 5-fluoruracil; MTX: methotrexate. Patients with adjuvant CRT underwent surgery before. Primary treated patients were treatment naive. n/a: not available. \#16 was previously treated with CIS/5-FU/cetuximab; \#17 and \#18 were previously treated with taxane/CIS/5-FU, gemcitabine, cetuximab, and pembrolizumab.

\section{Cell isolation}

B cells were separated from $\mathrm{PBMC}$ by negative selection using biotinylated anti-CD19 Ab and anti-biotin magnetic beads (B Cell Isolation Kit II, human, \#130-091151, Miltenyi Biotec,) according to the manufacturer's instruction. The purity of separated cells was always $>93 \%$ as monitored by flow cytometry. 


\section{Cell culture}

Freshly separated $\mathrm{CD} 19^{+} \mathrm{B}$ cells were seeded in flat bottom $96-w e l l$ plates $\left(10^{5}\right.$ cells/well $)$ and cultured in RPMI containing 10\% fetal bovine serum (PAN Biotech, Aidenbach, Germany), $4 \mathrm{mM}$ L-glutamine, $100 \mathrm{U} / \mathrm{mL}$ penicillin, and $100 \mathrm{mg} / \mathrm{mL}$ streptomycin (all from Gibco). B cells were stimulated with CD40L (10 ng/mL), hemagglutinin (423 ng/mL, both R\&D Systems, Minneapolis, MN), and IL-4 (200 IU/mL, CellGenix, Freiburg, Germany) and cultured for 7 days at $37^{\circ} \mathrm{C}$ and $5 \% \mathrm{CO}_{2}$. For in vitro testing of chemosensitivity as well as phenotypical and functional effects, the following soluble antineoplastic drugs were added in various concentrations: cisplatin (Teva, Ulm, Germany), methotrexate (Pfizer, Berlin, Germany), 5-FU (Medac, Hamburg, Germany), paclitaxel (Fresenius, Bad Homburg, Germany), and cetuximab (Merck, Darmstadt, Germany). Drug concentrations were in the range of concentrations measured in cancer patients [36]. Cell proliferation was measured by flow cytometry in CFSE-based proliferation assays (Thermo Fisher Scientific, Waltham, MA).

\section{ATP hydrolysis}

CD19 ${ }^{+}$B cells $\left(3 \times 10^{4}\right.$ per well, viable cells counted in a trypan blue dye) obtained from $\mathrm{NC}$, after seven days of chemotherapeutic treatment, were incubated with $20 \mu \mathrm{M}$ exogenous ATP (Sigma-Aldrich, St. Louis, MO) in 96-well plates for $90 \mathrm{~min}$. The concentration of nonhydrolyzed ATP was determined by measuring the frequency of luminescent events in a luciferase-based detection system (ATPlite Luminescence Assay System, PerkinElmer, Waltham, MA) using a luminescence reader (Infinite ${ }^{\circledR} 200$ Pro, Tecan, Maennedorf, Switzerland). Control samples included wells with 'no cells' or 'no ATP'.

\section{Mass spectrometry}

$\mathrm{B}$ cells from $\mathrm{NC}$ were separated by magnetic immunobeads as described previously. For detection of ATP and 5'-AMP hydrolysis, 25,000 cells were incubated in $200 \mu \mathrm{L}$ PBS in 96-well plates in the presence of $20 \mu \mathrm{M}$ ATP for various time periods. Control wells contained PBS alone. All experiments were duplicated. Supernatants were collected, centrifuged for 2 minutes at $6,000 \times \mathrm{g}$, boiled for 2 minutes to inactivate ADO-degrading enzymes, and stored at $-80^{\circ} \mathrm{C}$ for subsequent analysis. Purines were measured using liquid chromatography-tandem mass spectrometry by selected reaction monitoring with ${ }^{13} \mathrm{C}_{10}$-ADO, ${ }^{13} \mathrm{C}_{10}-5^{\prime}$ AMP, and ${ }^{15} \mathrm{~N}_{4}$-inosine as internal standards. In this regard, samples were injected into an Acuity ultra-performance liquid chromatographic system (Waters, Milford, MA) and were separated with a C18 column (Waters UPLC BEH C18; 1.7 micron; $2.1 \times 100 \mathrm{~mm}$ ) using the following elution conditions: mobile phase $\mathrm{A}, 1 \%$ acetic acid in $\mathrm{H}_{2} \mathrm{O}$; mobile phase $\mathrm{B}$, methanol; flow rate, $0.3 \mathrm{~mL} / \mathrm{min}$; elution gradient
(A/B) was $99.5 \% / 0.5 \%$ (0 to 2 minutes), $98 \% / 2 \%$ (2 to 3 minutes), $85 \% / 15 \%$ (3 to 4 minutes), and $99.5 \% / 0.5 \%$ (4 to 5 minutes). Purine levels were analyzed with a TSQ Quantum-Ultra Triple Quadrupole mass spectrometer equipped with a heated electrospray ionization source. The mass spectrometer was operated in the positive ion mode and the following mass-to-charge transitions were monitored: $348 \rightarrow 136$ for $5^{\prime}$-AMP; $358 \rightarrow 141$ for ${ }^{13} \mathrm{C}_{10}-5^{\prime}$ AMP; $268 \rightarrow 136$ for ADO; $278 \rightarrow 141$ for ${ }^{13} \mathrm{C}_{10}$-ADO; 269 $\rightarrow 137$ for inosine; and $269 \rightarrow 137$ for ${ }^{15} \mathrm{~N}_{4}$-inosine.

\section{Statistics}

Statistical analyses were performed using GraphPad Prism Software (GraphPad Software, Inc., La Jolla, CA). Error bars, where displayed, indicate the standard deviation of the mean or median data from replicate experiments. Significance of differences between samples within figures was confirmed using paired or unpaired $t$ tests, depending on the experimental setting, with a significant level of $\alpha=0.05$. Correlations were calculated by the Spearman test considering $R^{2}>0.5$ to be significant.

\section{Author contributions}

$\mathrm{AZ}, \mathrm{UH}$, and SJ performed experiments; JD and SL analyzed results and prepared figures; EKJ performed mass spectrometry experiments, CB and PJS designed research; AZ and PJS wrote the paper; TKH, EKJ and CB edited the paper.

\section{CONFLICTS OF INTEREST}

None.

\section{FUNDING}

There are no potential conflicts of interest to disclose. The research was supported by the German Research Foundation (DFG) Grant \# SCHU 2536/3 (PJS), by NIH grants (EKJ) DK068575, DK079307, DK091190, HL109002, and by the University of Ulm 'Promotionsprogramm Experimentelle Medizin' (AZ).

\section{REFERENCES}

1. Zhang Y, Gallastegui N, Rosenblatt JD. Regulatory B cells in anti-tumor immunity. Int Immunol. 2015; 27:521-530.

2. Schmidt M, Hellwig B, Hammad S, Othman A, Lohr M, Chen Z, Boehm D, Gebhard S, Petry I, Lebrecht A, Cadenas C, Marchan R, Stewart JD, et al. A comprehensive analysis of human gene expression profiles identifies stromal immunoglobulin kappa $\mathrm{C}$ as a compatible prognostic marker in human solid tumors. Clin Cancer Res. 2012; 18:2695-2703. 
3. Mahmoud SM, Lee AH, Paish EC, Macmillan RD, Ellis IO, Green AR. The prognostic significance of B lymphocytes in invasive carcinoma of the breast. Breast Cancer Res Treat. 2012; 132:545-553.

4. Pretscher D, Distel LV, Grabenbauer GG, Wittlinger M, Buettner M, Niedobitek G. Distribution of immune cells in head and neck cancer: CD8+ T-cells and CD20+ B-cells in metastatic lymph nodes are associated with favourable outcome in patients with oro- and hypopharyngeal carcinoma. BMC Cancer. 2009; 9:292-2407-9-292.

5. Kroeger DR, Milne K, Nelson BH. Tumor-Infiltrating Plasma Cells Are Associated with Tertiary Lymphoid Structures, Cytolytic T-Cell Responses, and Superior Prognosis in Ovarian Cancer. Clin Cancer Res. 2016; 22:3005-3015.

6. Flynn NJ, Somasundaram R, Arnold KM, Sims-Mourtada J. The Multifaceted Roles of B Cells in Solid Tumors: Emerging Treatment Opportunities. Target Oncol. 2017; 12:139-152.

7. Zhang Y, Eliav Y, Shin SU, Schreiber TH, Podack ER, Tadmor T, Rosenblatt JD. B lymphocyte inhibition of anti-tumor response depends on expansion of Treg but is independent of B-cell IL-10 secretion. Cancer Immunol Immunother. 2013; 62:87-99.

8. Ammirante M, Luo JL, Grivennikov S, Nedospasov S, Karin M. B-cell-derived lymphotoxin promotes castrationresistant prostate cancer. Nature. 2010; 464:302-305.

9. Perricone MA, Smith KA, Claussen KA, Plog MS, Hempel DM, Roberts BL, St George JA, Kaplan JM. Enhanced efficacy of melanoma vaccines in the absence of B lymphocytes. J Immunother. 2004; 27:273-281.

10. Shalapour S, Font-Burgada J, Di Caro G, Zhong Z, Sanchez-Lopez E, Dhar D, Willimsky G, Ammirante M, Strasner A, Hansel DE, Jamieson C, Kane CJ, Klatte T, et al. Immunosuppressive plasma cells impede T-cell-dependent immunogenic chemotherapy. Nature. 2015; 521:94-98.

11. Mizoguchi A, Mizoguchi E, Takedatsu H, Blumberg RS, Bhan AK. Chronic intestinal inflammatory condition generates IL-10-producing regulatory B cell subset characterized by CD1d upregulation. Immunity. 2002; 16:219-230.

12. Lindner S, Dahlke K, Sontheimer K, Hagn M, Kaltenmeier C, Barth TF, Beyer T, Reister F, Fabricius D, Lotfi R, Lunov $\mathrm{O}$, Nienhaus GU, Simmet T, et al. Interleukin 21-induced granzyme B-expressing B cells infiltrate tumors and regulate T cells. Cancer Res. 2013; 73:2468-2479.

13. Zhou X, Su YX, Lao XM, Liang YJ, Liao GQ. CD19(+) IL-10(+) regulatory $B$ cells affect survival of tongue squamous cell carcinoma patients and induce resting CD4(+) T cells to CD4(+)Foxp3(+) regulatory T cells. Oral Oncol. 2016; 53:27-35.

14. Wang WW, Yuan XL, Chen H, Xie GH, Ma YH, Zheng YX, Zhou YL, Shen LS. CD19+CD24hiCD38hiBregs involved in downregulate helper $\mathrm{T}$ cells and upregulate regulatory $\mathrm{T}$ cells in gastric cancer. Oncotarget. 2015; 6:33486-33499. https://doi.org/10.18632/oncotarget.5588.

15. Shao Y, Lo CM, Ling CC, Liu XB, Ng KT, Chu AC, Ma YY, Li CX, Fan ST, Man K. Regulatory B cells accelerate hepatocellular carcinoma progression via CD40/CD154 signaling pathway. Cancer Lett. 2014; 355:264-272.

16. Zhang Y, Morgan R, Chen C, Cai Y, Clark E, Khan WN, Shin SU, Cho HM, Al Bayati A, Pimentel A, Rosenblatt JD. Mammary-tumor-educated B cells acquire LAP/TGF$\hat{\mathrm{I}}^{2}$ and PD-L1 expression and suppress anti-tumor immune responses. Int Immunol. 2016; 28:423-433.

17. Guan H, Lan Y, Wan Y, Wang Q, Wang C, Xu L, Chen Y, Liu W, Zhang X, Li Y, Gu Y, Wang Z, Xie F. PD-L1 mediated the differentiation of tumor-infiltrating CD19(+) $B$ lymphocytes and $\mathrm{T}$ cells in Invasive breast cancer. Oncoimmunology. 2016; 5: e1075112. doi:10.1080/21624 02X.2015.1075112.

18. Saze Z, Schuler PJ, Hong CS, Cheng D, Jackson EK, Whiteside TL. Adenosine production by human B cells and B cell-mediated suppression of activated T cells. * equal contribution. Blood. 2013; 122:9-18.

19. Schuler PJ, Harasymczuk M, Schilling B, Lang S, Whiteside TL. Separation of human CD4+CD39+ T cells by magnetic beads reveals two phenotypically and functionally different subsets. J Immunol Methods. 2011; 369:59-68.

20. Schuler PJ, Westerkamp AM, Kansy BA, Bruderek K, Dissmann PA, Dumitru CA, Lang S, Jackson EK, Brandau S. Adenosine metabolism of human mesenchymal stromal cells isolated from patients with head and neck squamous cell carcinoma. Immunobiology. 2017; 222:66-74.

21. Schuler PJ, Macatangay BJ, Saze Z, Jackson EK, Riddler SA, Buchanan WG, Hilldorfer BB, Mellors JW, Whiteside TL, Rinaldo CR. CD4(+)CD73(+) T cells are associated with lower $\mathrm{T}$-cell activation and $\mathrm{C}$ reactive protein levels and are depleted in HIV-1 infection regardless of viral suppression. AIDS. 2013; 27:1545-1555.

22. Schuler PJ, Saze Z, Hong CS, Muller L, Gillespie DG, Cheng D, Harasymczuk M, Mandapathil M, Lang S, Jackson EK, Whiteside TL. Human CD4+ CD39+ regulatory $\mathrm{T}$ cells produce adenosine upon co-expression of surface CD73 or contact with CD73+ exosomes or CD73+ cells. Clin Exp Immunol. 2014; 177:531-543.

23. Beckenkamp A, Santana DB, Bruno AN, Calil LN, Casali EA, Paccez JD, Zerbini LF, Lenz G, Wink MR, Buffon A. Ectonucleotidase expression profile and activity in human cervical cancer cell lines. Biochem Cell Biol. 2014; 92:95-104.

24. Ohta A, Gorelik E, Prasad SJ, Ronchese F, Lukashev D, Wong MK, Huang X, Caldwell S, Liu K, Smith P, Chen JF, Jackson EK, Apasov S, et al. A2A adenosine receptor protects tumors from antitumor T cells. Proc Natl Acad Sci U S A. 2006; 103:13132-13137.

25. Schuler PJ, Schilling B, Harasymczuk M, Hoffmann TK, Johnson J, Lang S, Whiteside TL. Phenotypic and 
functional characteristics of CD4+ CD39+ FOXP3+ and CD4+ CD39+ FOXP3neg T-cell subsets in cancer patients. Eur J Immunol. 2012; 42:1876-1885.

26. Kasama H, Sakamoto Y, Kasamatsu A, Okamoto A, Koyama T, Minakawa Y, Ogawara K, Yokoe H, Shiiba M, Tanzawa H, Uzawa K. Adenosine A2b receptor promotes progression of human oral cancer. BMC Cancer. 2015; 15:563-015-1577-2.

27. Vecchio EA, Tan CY, Gregory KJ, Christopoulos A, White PJ, May LT. Ligand-Independent Adenosine A2B Receptor Constitutive Activity as a Promoter of Prostate Cancer Cell Proliferation. J Pharmacol Exp Ther. 2016; 357:36-44.

28. Turcotte M, Spring K, Pommey S, Chouinard G, Cousineau I, George J, Chen GM, Gendoo DM, Haibe-Kains B, Karn T, Rahimi K, Le Page C, Provencher D, et al. CD73 is associated with poor prognosis in high-grade serous ovarian cancer. Cancer Res. 2015; 75:4494-4503.

29. Leclerc BG, Charlebois R, Chouinard G, Allard B, Pommey S, Saad F, Stagg J. CD73 Expression Is an Independent Prognostic Factor in Prostate Cancer. Clin Cancer Res. 2016; 22:158-166.

30. Eini H, Frishman V, Yulzari R, Kachko L, Lewis EC, Chaimovitz C, Douvdevani A. Caffeine promotes anti-tumor immune response during tumor initiation: Involvement of the adenosine A2A receptor. Biochem Pharmacol. 2015; 98:110-118.

31. Beavis PA, Milenkovski N, Henderson MA, John LB, Allard B, Loi S, Kershaw MH, Stagg J, Darcy PK. Adenosine Receptor 2A Blockade Increases the Efficacy of Anti-PD-1 through Enhanced Antitumor T-cell Responses. Cancer Immunol Res. 2015; 3:506-517.

32. Mittal D, Young A, Stannard K, Yong M, Teng MW, Allard B, Stagg J, Smyth MJ. Antimetastatic effects of blocking PD-1 and the adenosine A2A receptor. Cancer Res. 2014; 74:3652-3658.

33. Schuler PJ, Harasymczuk M, Schilling B, Saze Z, Strauss L, Lang S, Johnson JT, Whiteside TL. Effects of adjuvant chemoradiotherapy on the frequency and function of regulatory $\mathrm{T}$ cells in patients with head and neck cancer. Clin Cancer Res. 2013; 19:6585-6596.

34. Jie HB, Schuler PJ, Lee SC, Srivastava RM, Argiris A, Ferrone S, Whiteside TL, Ferris RL. CTLA-4(+) Regulatory $\mathrm{T}$ Cells Increased in Cetuximab-Treated Head and Neck Cancer Patients Suppress NK Cell Cytotoxicity and Correlate with Poor Prognosis. Cancer Res. 2015; 75:2200-2210.

35. Schuler PJ, Harasymczuk M, Visus C, Deleo A, Trivedi S, Lei Y, Argiris A, Gooding W, Butterfield LH, Whiteside TL, Ferris RL. Phase I dendritic cell p53 peptide vaccine for head and neck cancer. Clin Cancer Res. 2014; 20:2433-2444.

36. Schuler PJ, Trellakis S, Greve J, Bas M, Bergmann C, Bolke E, Lehnerdt G, Mattheis S, Albers AE, Brandau S, Lang $\mathrm{S}$, Whiteside TL, Bier $\mathrm{H}$, et al. In vitro chemosensitivity of head and neck cancer cell lines. Eur J Med Res. 2010; 15:337-344.

37. Zhang $\mathrm{C}$, Xin $\mathrm{H}$, Zhang W, Yazaki PJ, Zhang Z, Le K, Li W, Lee H, Kwak L, Forman S, Jove R, Yu H. CD5 Binds to Interleukin-6 and Induces a Feed-Forward Loop with the Transcription Factor STAT3 in B Cells to Promote Cancer. Immunity. 2016; 44:913-923.

38. Jackson SW, Hoshi T, Wu Y, Sun X, Enjyoji K, Cszimadia E, Sundberg C, Robson SC. Disordered Purinergic Signaling Inhibits Pathological Angiogenesis in Cd39/ Entpd1-Null Mice. Am J Pathol. 2007; 171:1395-1404.

39. Stagg J, Divisekera U, Duret H, Sparwasser T, Teng MW, Darcy PK, Smyth MJ. CD73-deficient mice have increased antitumor immunity and are resistant to experimental metastasis. Cancer Res. 2011; 71:2892-2900.

40. Yegutkin GG, Marttila-Ichihara F, Karikoski M, Niemela J, Laurila JP, Elima K, Jalkanen S, Salmi M. Altered purinergic signaling in CD73-deficient mice inhibits tumor progression. Eur J Immunol. 2011; 41:1231-1241.

41. Leth-Larsen R, Lund R, Hansen HV, Laenkholm AV, Tarin D, Jensen ON, Ditzel HJ. Metastasis-related plasma membrane proteins of human breast cancer cells identified by comparative quantitative mass spectrometry. Mol Cell Proteomics. 2009; 8:1436-1449.

42. Serra S, Horenstein AL, Vaisitti T, Brusa D, Rossi D, Laurenti L, D'Arena G, Coscia M, Tripodo C, Inghirami G, Robson SC, Gaidano G, Malavasi F, et al. CD73-generated extracellular adenosine in chronic lymphocytic leukemia creates local conditions counteracting drug-induced cell death. Blood. 2011; 118:6141-6152.

43. Loi S, Pommey S, Haibe-Kains B, Beavis PA, Darcy PK, Smyth MJ, Stagg J. CD73 promotes anthracycline resistance and poor prognosis in triple negative breast cancer. Proc Natl Acad Sci U S A. 2013; 110:11091-11096.

44. Tsuchiya A, Nishizaki T. Anticancer effect of adenosine on gastric cancer via diverse signaling pathways. World $\mathrm{J}$ Gastroenterol. 2015; 21:10931-10935.

45. Barry CP, Lind SE. Adenosine-mediated killing of cultured epithelial cancer cells. Cancer Res. 2000; 60:1887-1894.

46. Schrier SM, van Tilburg EW, van der Meulen H, Ijzerman AP, Mulder GJ, Nagelkerke JF. Extracellular adenosineinduced apoptosis in mouse neuroblastoma cells: studies on involvement of adenosine receptors and adenosine uptake. Biochem Pharmacol. 2001; 61:417-425.

47. Talme T, Bergdahl E, Sundqvist KG. Methotrexate and its therapeutic antagonists caffeine and theophylline, target a motogenic T-cell mechanism driven by thrombospondin-1 (TSP-1). Eur J Immunol. 2016; 46:1279-1290.

48. Malaviya AN. Methotrexate intolerance in the treatment of rheumatoid arthritis (RA): effect of adding caffeine to the management regimen. Clin Rheumatol. 2017; 36:279-285.

49. Tsujimoto S, Yanagimachi M, Tanoshima R, Urayama KY, Tanaka F, Aida N, Goto H, Ito S. Influence of ADORA2A gene polymorphism on leukoencephalopathy risk in 
MTX-treated pediatric patients affected by hematological malignancies. Pediatr Blood Cancer. 2016; 63:1983-1989.

50. Majumdar S, Aggarwal BB. Methotrexate suppresses NF-kappaB activation through inhibition of IkappaBalpha phosphorylation and degradation. J Immunol. 2001; 167:2911-2920.

51. Figueiro F, de Oliveira CP, Bergamin LS, Rockenbach L, Mendes FB, Jandrey EH, Moritz CE, Pettenuzzo LF, Sevigny J, Guterres SS, Pohlmann AR, Battastini AM. Methotrexate up-regulates ecto-5'-nucleotidase/CD73 and reduces the frequency of T lymphocytes in the glioblastoma microenvironment. Purinergic Signal. 2016; 12:303-312.
52. Schuler PJ, Laban S, Doescher J, Bullinger L, Hoffmann TK. Novel Treatment Options in Head and Neck Cancer. Oncol Res Treat. 2017; 40:342-346.

53. Vijayan D, Young A, Teng MWL, Smyth MJ. Targeting immunosuppressive adenosine in cancer. Nat Rev Cancer. 2017. https://doi.org/10.1038/nrc.2017.86.

54. Maj T, Wang W, Crespo J, Zhang H, Wang W, Wei S, Zhao L, Vatan L, Shao I, Szeliga W, Lyssiotis C, Liu JR, Kryczek $\mathrm{I}$, et al. Oxidative stress controls regulatory $\mathrm{T}$ cell apoptosis and suppressor activity and PD-L1-blockade resistance in tumor. Nat Immunol. 2017. https://doi.org/10.1038/ni.3868. 